\title{
Comparative Study on Performance Assessment of Steel Structure with Lead Rubber Bearing System (Myanmar Rubber) and Fixed Base
}

\author{
Nwe Nwe Win, and Zaw Min Htun
}

\begin{abstract}
Seismic isolation is a technique that has been used around the world to protect building structures, non structural components and content from the damaging effects of earthquake ground shaking. The aim of this study is the use of lead rubber bearing (LRB) as an isolation device and then to compare various parameters between fixed base condition and isolated base condition. In this study, comparative advantages for using lead rubber bearing (LRB) isolation systems are mainly investigated by performing nonlinear dynamic time history analyses for design basic earthquake (DBE) seismic demand level. The comparison process has been carried out on structural performance of the structure with storey displacement, storey acceleration, and storey drift ratio. In performance assessment phase, probable damage cost, repair time and rate of injuries are computed using fragility curves and FEMA P-58 methodology in Performance Assessment Calculation Tool (PACT). The lead rubber bearing system (Myanmar rubber, RSS-3) was developed to reduce damage cost, repair time and rate of injuries of the buildings subject to earthquake.
\end{abstract}

Keywords-fixed base, lead rubber bearing, nonlinear time history analyses, performance assessment.

\section{INTRODUCTION}

Buildings are vulnerable to earthquake ground motions. Vulnerability of this kind of structures has been patent after the strong earthquakes and hurricanes that have hit different regions around the world and have caused their collapse with the consequent loss of lives. Civil engineering structures are to be protected from hazardous phenomena like seismic motions. In order to make structures safer against these phenomena, researchers have taken advantage of the fact that, by the principle of energy conservation, damping devices can be added to the structure as protective systems. To help reduce the loss from earthquake events, seismic protective devices emerged in recent decades to improve the performance of building structures against earthquake loads. Base isolation technique is one of the most widely implemented seismic protection systems in earthquake prone areas. The term "base" refers to the foundation of a structure and "isolation" refers to reduced interaction between the ground and the structure

Manuscript received November. 3,2016

Nwe Nwe Win is a $\mathrm{PhD}$ candidate in Department of Civil Engineering, Mandalay Technological University, Mandalay, Myanmar

Zaw Min Htun is an Associate Professor in Department of Civil Engineering, Mandalay Technological University, Mandalay, Myanmar resting over it. Base isolation is one of the most powerful tools of earthquake engineering pertaining to the passive structural vibration control technologies. The system reduces the structural and non structural damage to a building subjected to seismic forces [1].

Seismic isolation is the separation of the structure from its base to negotiate the destructive movement of the ground by providing flexibility and energy dissipation capability through the insertion of isolators between the foundation and the building structure [2]. Unlike the conventional design approach, which is based on an increased resistance (strengthening) of the structures, the seismic isolation concept is aimed at a significant reduction of dynamic loads induced by the earthquake at the base of the structures themselves [3]. The traditional methods often result in high floor accelerations for stiff buildings, or large interstory drifts for flexible buildings. Because of this, the building contents and non structural components may suffer significant damage during a major earthquake. In order to minimize interstory drifts, in addition to reducing floor accelerations, the concept of base isolation is increasingly being adopted [4]. Storey displacements in the structure together with the accelerations shall be reduced significantly. While this reduction in the accelerations protects the non structural elements from the acceleration originated damages, the reduction in the storey displacements shall allow both the structural and non structural elements survive the earthquake without any damage or with little damage. Base isolation has specially designed interface at the structural base or within the structure, which can reduce or filter out the forces transmitted from the ground. These systems dissipate part of the energy created on the structure by the earthquake effect and thus increase the seismic performance of the structure and of its contents.

A base isolation effectively protects structures against extreme earthquake without sacrificing performance during the move frequent, moderate seismic events. With the conventional methods of building earthquake resistant structures, structure may survive of the earthquake but it is very likely that it may not remain operational after any major seismic event. But base isolation technique not only prevents the earthquake from any serious damages but also maintains functionality i.e. building remains operational after earthquake [5].

Invention of lead rubber bearing (1970's) gave a new dimension to the design of base isolated structure [6]. The use 
of lead rubber bearings have been moved to popular phenomena in recent days. A number of both past and recent researches in the area of base isolation have spotlighted on the innovation [7].

Santosh H.P., M and K [8] presented the work on seismic analysis of low to medium rise building for base isolation. The lead rubber isolator was used as an isolating device. The analysis was done by using STAAD Pro software. The six storey building were analysed both by considering the base as fixed base structure and then by considering it as a base isolated by means of lead rubber bearings. The analytical results show the reduction in storey acceleration and the storey shear in case of base isolated structure compared to non isolated structure.

Torunbalci N. and $\mathrm{O}$ [9] presented the analytical study on mid-storey building by considering various seismic isolation techniques. For a case study, a six storey building was analysed by using three dimensional nonlinear time history analysis. The analysis was done on the basis of various seismic isolation and energy dissipating alternatives. Alternatives which included rubber bearings, friction pendulum bearings, additional isolated storey and viscous dampers.

Though the application of isolator is going to be very familiar all over the world, there is a lack of proper research to implement the device practically for local buildings in Mandalay, Myanmar as per the local requirements. Many types of isolation system have been developed elsewhere in the world to provide flexibility and damping to a structure in the event of seismic attack. Among the categories, lead rubber bearing (LRB) is the most commonly used isolator nowadays. The analysis and design of isolators for 8-storeyed residential steel building in Mandalay were performed.

\section{LEAD RUBBER BEARING}

Lead rubber bearings that were first invented in New Zealand, have been extensively used both in the United States and in Japan. China has recently joined this group. The lead rubber bearing is composed of an elastomeric bearing made by laminated rubber layers with steel shim plates, cover plates, and lead core located on its center. The typical lead rubber bearing is shown in Fig.1.This lead rubber bearing can combine the function of isolation and recentering in a single unit (i.e.: elastomeric bearing), thereby giving structural support, horizontal flexibility and recentering force to the isolation system [10]. Therefore one device can support the structure vertically by providing a horizontal displacement and increasing the damping of isolation system in desired value. The steel plates control the lead-shape during large plastic deformation. Thus, when isolator is subject to a large displacement, the lead insert is forced by steel shims to deform in shear and absorb to deform in shear and absorb energy. A major advantage of the lead rubber bearing is that it combines the functions of rigidity at service load levels, flexibility at earthquake load levels and damping into a single compact unit.

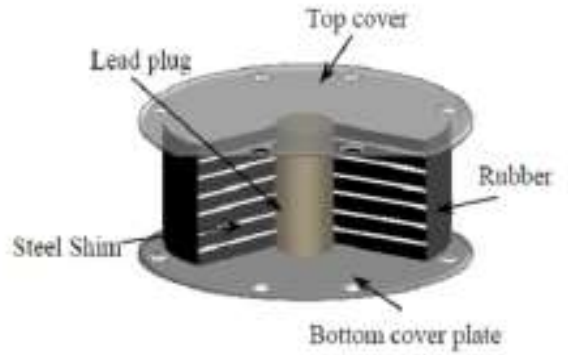

Fig. 1. Lead rubber bearing.

Myanmar lead rubber bearings are expected to be widely used in those areas. In this paper, the RSS-3 type Myanmar lead rubber bearings are studied. The required experimental tests are conducted to determine the properties of the materials in Rubber Research Development Centre. The experimental test results of Myanmar rubber properties for two types of specimens are shown in Table. I

TABLE I: TEST RESULTS FOR PROPERTIES OF MYANMAR RUBBER

\begin{tabular}{cccc}
\hline \hline $\begin{array}{c}\text { Rubber } \\
\text { Hardness } \\
\text { IRHD }\end{array}$ & $\begin{array}{c}\text { Young's } \\
\text { Modulus E } \\
\left(\mathrm{kip} / \mathrm{ft}^{2}\right)\end{array}$ & $\begin{array}{c}\text { Shear } \\
\text { Modulus G } \\
\left(\mathrm{kip} / \mathrm{ft}^{2}\right)\end{array}$ & $\begin{array}{c}\text { Elongation } \\
\text { at Break } \\
(\%)\end{array}$ \\
\hline 55 & 23.492 & 5.855 & 463 \\
60 & 39.154 & 9.327 & 412 \\
\hline \hline
\end{tabular}

\section{Structural Modal}

A model of $96 \mathrm{ft}$ length and $60 \mathrm{ft}$ width 8-storeyed building was created with steel columns and beams as represented in Fig.2. The steel superstructure had a lateral system of special moment frames (SMF) in both the transverse and longitudinal directions, and that structural system was used for both of the fixed base and isolated base buildings designed for this study. Building was assumed to be located in Mandalay area and be subjected to a $10 \%$ probability of exceedance in 50 year $(10 \%$ in 50 years) seismic hazard corresponding to design based earthquake (DBE). According to Myanmar National Building Code (MNBC), the mapped spectral accelerations for 0.2- and 1 -s periods were taken as $2.01 \mathrm{~g}$ and $0.8 \mathrm{~g}$, respectively. The response modification factors were taken as the value of 8 consistent with special moment frames structure. The sizes of structural members were designed in accordance with AISC-LRFD.

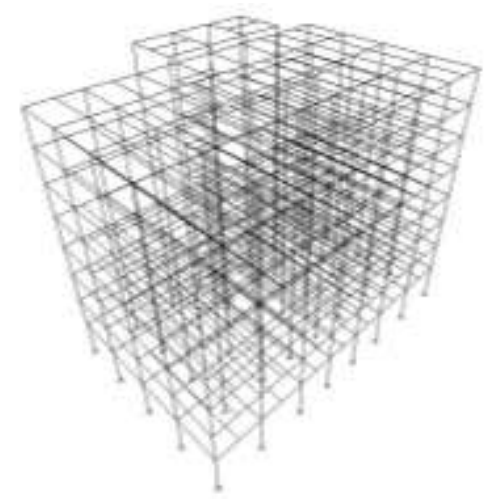

Fig. 2. 3D view of the proposed building. 


\section{A. Selection of Isolation System}

From the previous researches it has been found out that the structural shifted period is one of the most important factors in designing isolation systems. Furthermore, for the low and medium rise buildings, the application of isolation system becomes more appropriate when the structural shifted period lies in the range of the 1.5 to 3 seconds. Therefore, for designing isolation systems and structures, the period around 2 seconds is selected to be the main factor. The total effective stiffness of the isolation system and the designed displacement are two important factors affecting the elastic forces. In the case of designing seismic isolators, economically, these two parameters should conservatively be minimized. Consequently, in this research, isolators were designed according to the provided minimum elastic force as second factor. Bearings can be designed to carry different magnitudes of displacement by adjusting the diameter and curvature of the bearing surface.

One isolator is designed of the most critical column load in buildings. The properties of the designed isolators are shown in the Table. II. The main parameters are the effective stiffness $\left(\mathrm{K}_{\text {eff }}\right)$, effective damping $\left(\mathrm{D}_{\text {eff }}\right)$, isolator diameter $\left(\mathrm{D}_{\mathrm{i}}\right)$, lead core diameter (d), height of the isolator $(\mathrm{H})$ and the number of layers (n).

TABLE II: PROPERTIES OF THE DESIGNED OF LEAD RUBBER BEARING

\begin{tabular}{ccccccc}
\hline \hline Type & $\begin{array}{c}\mathrm{K}_{\text {eff }} \\
(\mathrm{k} / \mathrm{in})\end{array}$ & $\begin{array}{c}\mathrm{D}_{\text {eff }} \\
(\%)\end{array}$ & $\begin{array}{c}\mathrm{D}_{\mathrm{i}} \\
(\mathrm{in})\end{array}$ & $\begin{array}{c}\mathrm{d} \\
(\mathrm{in})\end{array}$ & $\begin{array}{c}\mathrm{H} \\
(\mathrm{in})\end{array}$ & $\mathrm{n}$ \\
\hline LRB1 & 5.57 & 18.98 & 31 & 3.5 & 18.63 & 28 \\
LRB2 & 8.01 & 18.98 & 37 & 3.5 & 18.64 & 24 \\
LRB3 & 11.04 & 18.98 & 44 & 3.5 & 18.19 & 20 \\
\hline \hline
\end{tabular}

\section{RESUlts}

This section discusses the results obtained from analysis phase and performance assessment phase.

\section{A. Analysis Phase Results}

The figures in the section illustrate the results obtained from the analysis phase. The fixed base response is shown in blue and the isolated base response is shown in red in each figures.

1) Comparison of Storey Displacement: The Fig. 3 and Fig. 4 show comparison of storey displacement for the structures, both in $\mathrm{X}$ and $\mathrm{Y}$ direction respectively.

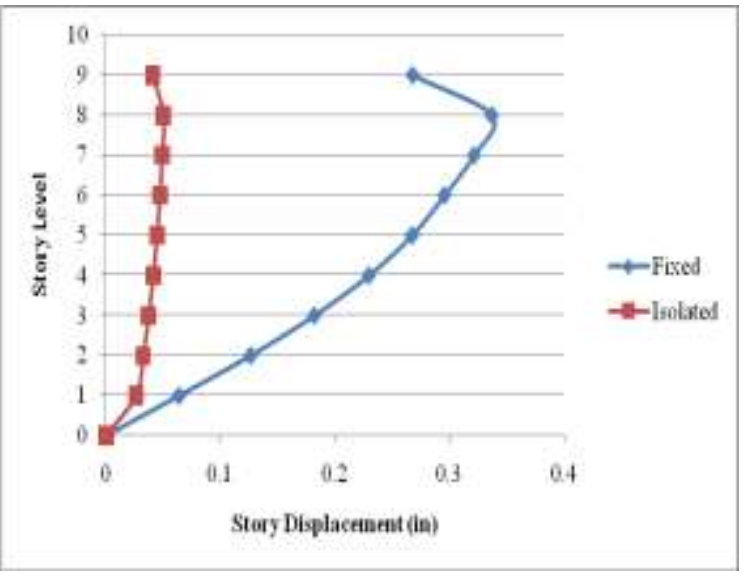

Fig. 3 Comparison results of storey displacement in $\mathrm{X}$ direction.
From Fig.3, it can be seen that the storey displacement of fixed base is zero at the base and increases as storey height increases. But the storey displacement of isolated base increases at a comparatively slower rate when storey height increases. However, the reduction in displacement is $84.65 \%$ at the top for isolated model in comparison with the fixed base model. Difference between the displacement at top and at base level is less with isolated base as compare to fixed base.

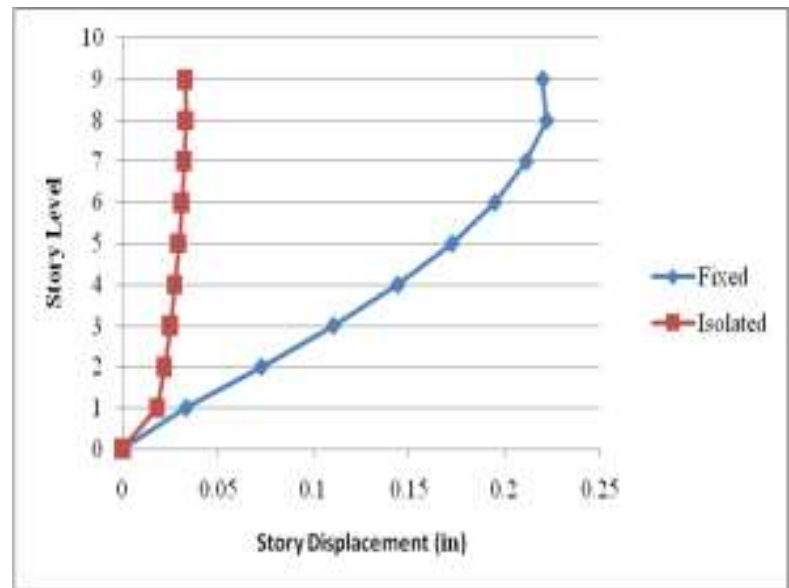

Fig. 4 Comparison results of storey displacement in Y direction.

From Fig.4, it can be seen that the storey displacement of fixed base is zero at the base and increases as storey height increases. But the storey displacement of isolated base increases at a comparatively slower rate when storey height increases. The reduction in displacement is $85.0626 \%$ at the top for isolated model in comparison with the fixed base model, in $\mathrm{Y}$ direction.

2) Comparison of Storey Acceleration: The Fig.5 and Fig.6 show comparison of storey acceleration for the structures, both in $\mathrm{X}$ and $\mathrm{Y}$ direction respectively. An isolation system minimizes the transmitted acceleration to the superstructure thereby producing a lower effective stiffness in higher damping.

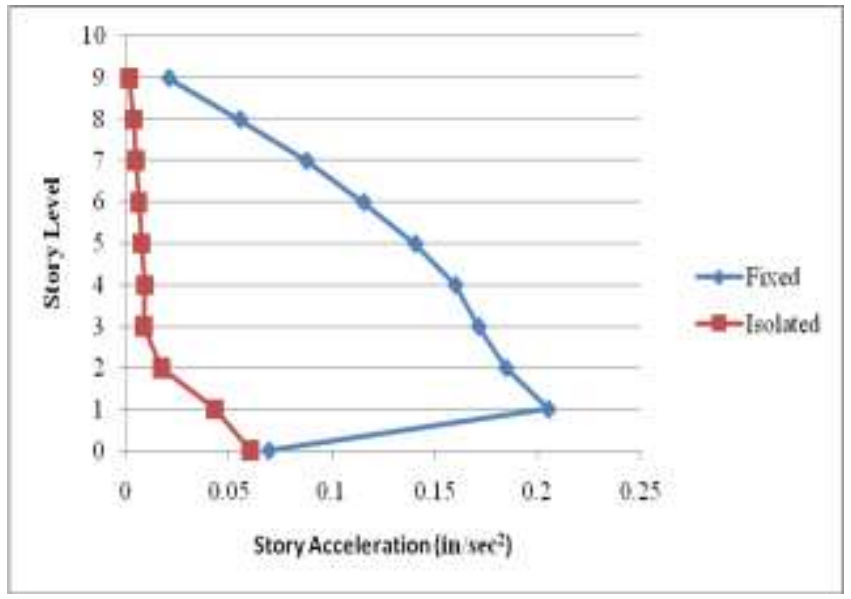

Fig. 5 Comparison results of storey acceleration in $\mathrm{X}$ direction.

From Fig.5, it can be seen that maximum acceleration is 
$0.2052 \mathrm{in} / \mathrm{s}^{2}$ in case of fixed base model. Whereas isolated model is $0.0603 \mathrm{in} / \mathrm{s}^{2}$ comparatively less than that of fixed base model. The reduction in the acceleration at the top floor is $92.217 \%$ and bottom floor is $12.8789 \%$ for isolated model in comparison with fixed base model.



Fig. 6 Comparison results of storey acceleration in Y direction.

From Fig.6, it can be seen that maximum acceleration is $0.2277 \mathrm{in} / \mathrm{s}^{2}$ in case of fixed base model. Whereas isolated model is $0.0456 \mathrm{in} / \mathrm{s}^{2}$ comparatively less than that of fixed base model. The reduction in the acceleration at the top floor is $89.174 \%$ and bottom floor is $69.5076 \%$ for isolated model in comparison with fixed base model.

3) Comparison of Storey Drift Ratio: The Fig.7 and Fig.8 show comparison of storey drift ratio for the structure, both in $\mathrm{X}$ and $\mathrm{Y}$ direction.

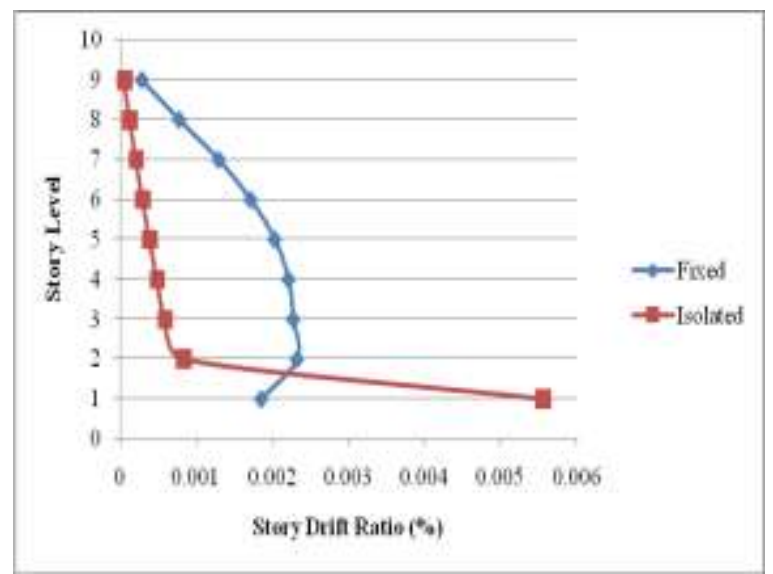

Fig. 7 Comparison results of storey drift ratio in $\mathrm{X}$ direction.

From Fig.7, it can be seen that the storey drift ratio is higher at lower floors in case of fixed base model and it decreases drastically move to the top floors. Storey drift ratio is comparatively lower in lower floors of fixed base model than in case of isolated model and decreases move to the top floors. The average reduction in storey drift is $42.102 \%$ for isolated model in comparison with the fixed base model.

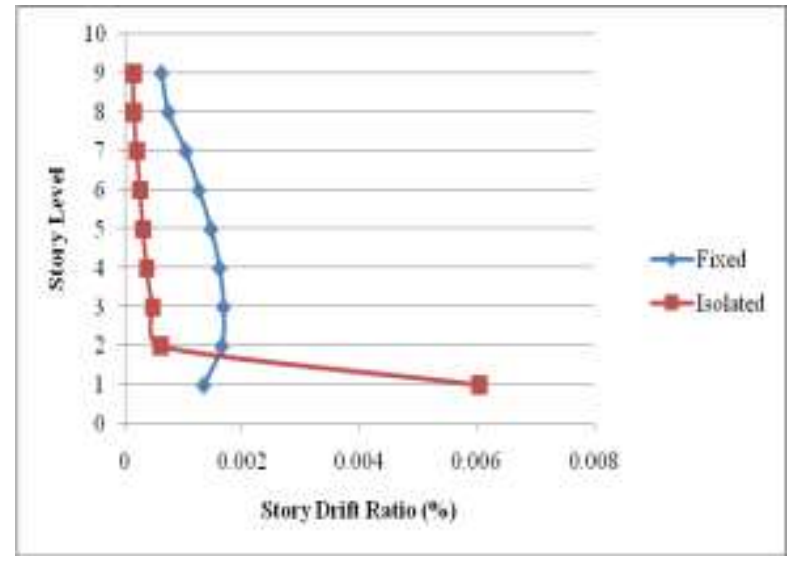

Fig. 8 Comparison results of storey drift ratio in Y direction.

From Fig.8, it can be seen that the storey drift ratio is higher at lower floors in case of fixed base model and it decreases drastically move to the top floors. Storey drift ratio of fixed base model is comparatively lower in lower floors and higher in upper floors than in case of isolated model. The average reduction in storey drift is $25.118 \%$ for isolated model in comparison with the fixed base model.

4) Comparison of Structural Period: Structural period of fixed base structure and base isolated structure using lead rubber bearing are compared. Structural period for all cases was compared and shown in Table III. Structural period increases in the base isolated structures.

TABLE III: COMPARISON OF STRUCTURAL PERIOD FOR LRB AND FIXED

\begin{tabular}{cc}
\hline \hline Condition & Structural Period (seconds) \\
\hline Fixed & 1.4452 \\
\hline LRB & 0.6376 \\
\hline \hline
\end{tabular}

The above table.III shows that structural period of lead rubber bearing more increases 0.8076 seconds than fixed base building.

\section{B. Performance Assessment Phase Results}

1) Comparison of Damage Cost: The Fig. 9 and Fig.10 show damage cost for different types of base condition.

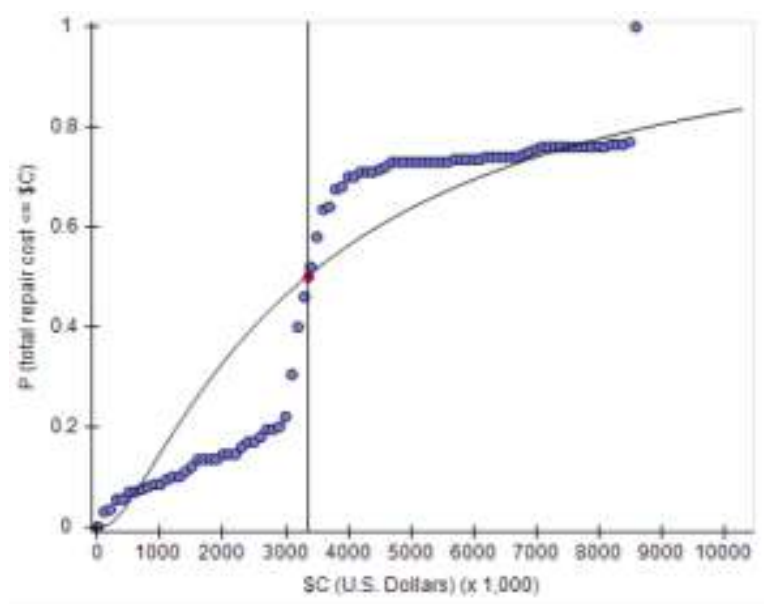

Fig. 9 Damage cost results for fixed base. 
Fig.9 illustrates the probability of the fixed base apartment building incurring damage costs for DBE level seismic events. The $\mathrm{X}$-axis shows the damage costs in thousands of dollars and the Y-axis gives the probability of repair costs not surpassing the given damage costs. Accordingly, the fixed base building has a 50\% probability of incurring $\$ 3.367$ million in damage costs when subjected to DBE level seismic events.

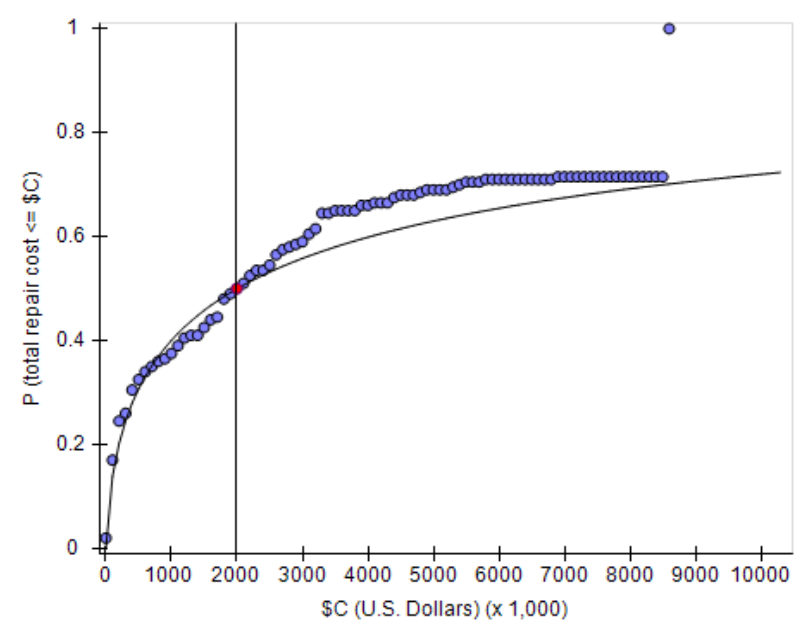

Fig. 10 Damage cost results for isolated base.

Fig.10 illustrates the isolated base building have a $50 \%$ probability of incurring $\$ 2$ million in damage costs when subjected to DBE level seismic events.

2) Comparison of Repair Time: The Fig.11 and Fig.12 show repair time for different types of base condition.

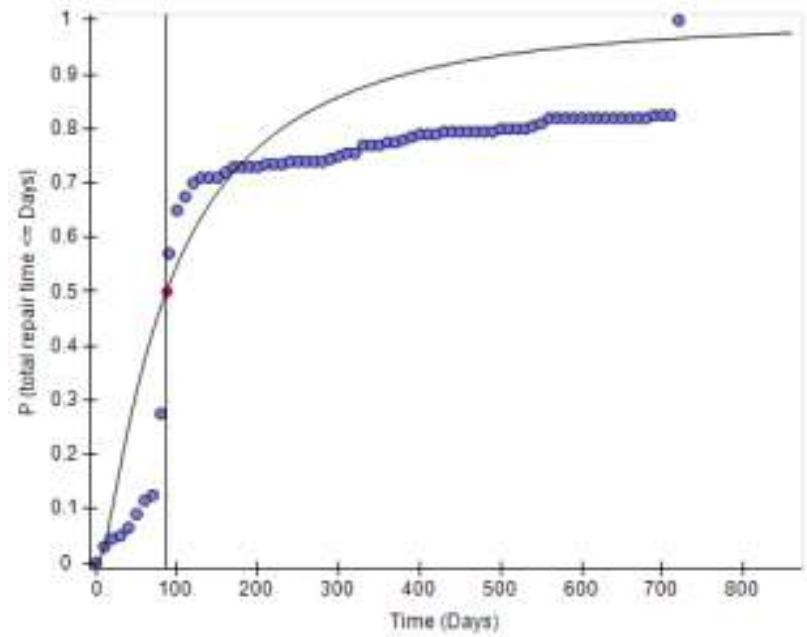

Fig. 11 Repair time results for fixed base.

Fig.11 shows the probability of repair time for the fixed base building subjected to DBE level of seismic demands occurs 88 days.

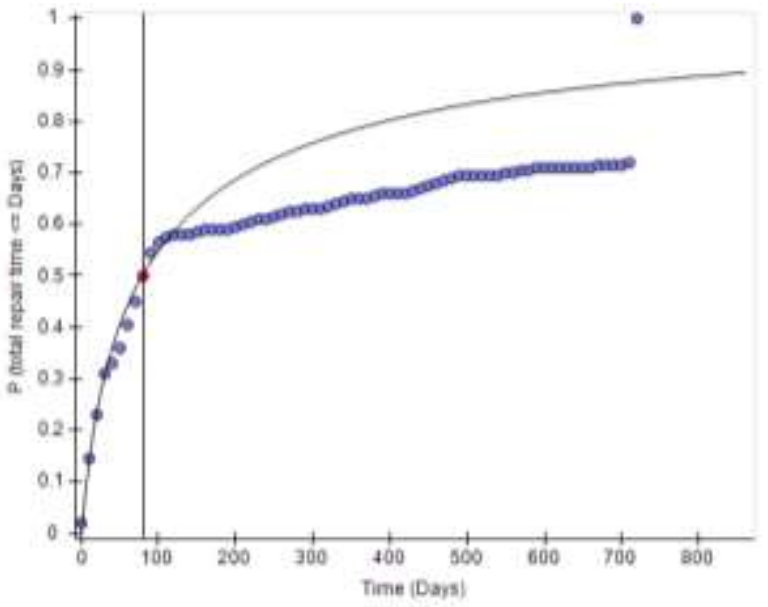

Fig. 12 Repair time results for isolated base.

Fig. 12 gives the probability of repair time being incurred 80 days for the isolated base building subjected to DBE level of seismic demands.

3) Comparison of Injuries: The Fig.13 and Fig.14 show injuries for different types of base condition.

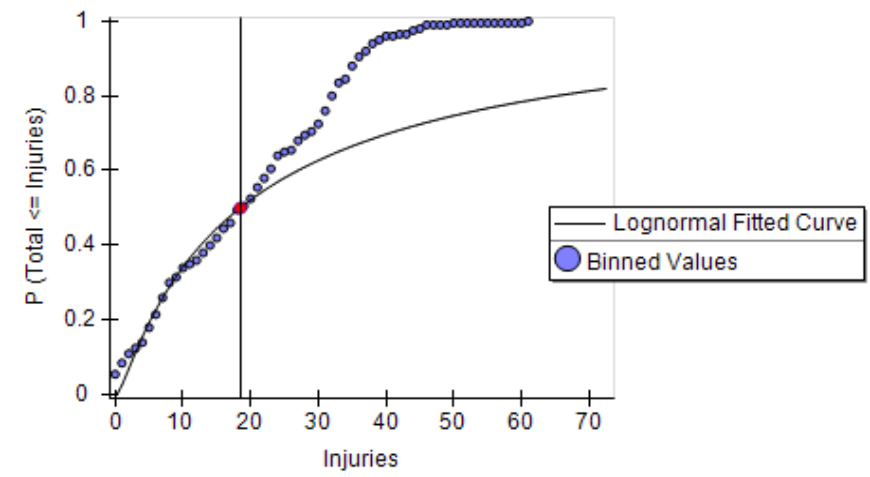

Fig. 13 Injuries results for fixed base.

When subject to DBE level seismic events, the fixed base apartment building has a $50 \%$ probability of incurring 18.5 injuries as shown in Fig.13.

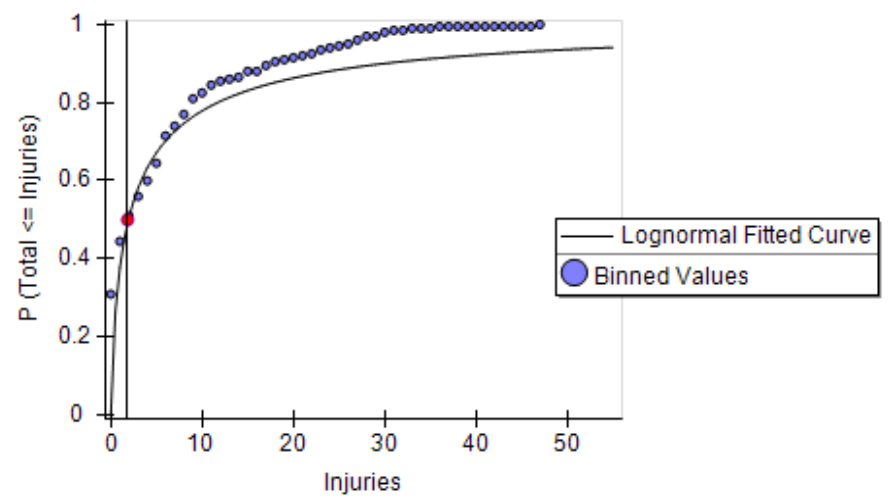

Fig. 14 Injuries results for isolated base.

Fig.14 gives base isolation in the apartment building caused a $50 \%$ probability of incurring 1.85 injuries for DBE level seismic demands.

The damage cost results for each building and seismic 
demand level are summarized in the Table.IV.

TABLE IV: DAMAGE COST RESULTS

\begin{tabular}{lc}
\hline \hline Condition & $\begin{array}{c}\text { DBE Damage Cost } \\
(\$ \text { Million })\end{array}$ \\
\hline Fixed Base & 3.4 \\
Isolated Base & 2 \\
Savings & 1.4 \\
\hline \hline
\end{tabular}

Table IV shows base isolation reduces damage costs by $\$ 1.4$ million, equal to $41 \%$ reduction in damage costs.

By using the proportional cost of the base isolation system and the estimated total construction cost for the building in this study, the following calculations are performed, and the results are summarized in Table V.

Total Construction Cost $=\$ 8.6$ millions $(\$ 165$ per Square Feet)

$10 \%($ Base Isolation + Maintenance Cost $)=\$ 0.86$ millions

TABLE V: TOTAL DAMAGE COST SAVING RESULTS

\begin{tabular}{cccc}
\hline \hline $\begin{array}{c}\text { Seismic } \\
\text { Demand } \\
\text { Level }\end{array}$ & $\begin{array}{c}\text { Damage } \\
\text { Saving } \\
\text { (\$ Million) }\end{array}$ & $\begin{array}{c}\text { Isolation } \\
\text { Cost } \\
\text { (\$ Million) }\end{array}$ & $\begin{array}{c}\text { Total } \\
\text { Saving } \\
\text { (\$ Million) }\end{array}$ \\
\hline \hline DBE & 1.4 & 0.86 & 0.54 \\
\hline
\end{tabular}

Table $\mathrm{V}$ shows the implementation of base isolation technology would likely achieve $\$ 0.6$ million in total saving for the 8-storeyed steel apartment building.

\section{CONCLUSIONS}

The design of lead rubber bearing for multi storey building in risk seismicity region has been carried out and the nonlinear dynamic structural responses are evaluated. By incorporation the innovative isolator,the structural elements of multi storey building under lateral earthquake load experiences lower in lateral deformation. Ground motion records for time history analysis are obtained from PEER ground motion database web site based on ASCE code spectrum. The saving in damage costs,performance assessment reported in this study are underestimated due to the number of components and fragility curves available in PACT. From the results of present study, the following conclusions are drawn;

- The story accelerations are reduced significantly in the isolated base building than the fixed base building.

- The structural period of the isolated base structures increases 2.2666 times compared to the fixed base structure.

- According to PACT, total savings in damage cost would be millions of dollars greater than the cost of the isolation system.

- And then, the reduction in repair time is $9.1 \%$ for the isolated structure in comparison with the fixed base structure.

- The rate of injuries of isolated structure is $90 \%$ smaller than that of fixed base structure.

\section{ACKNOWLEDGMENT}

The authors would like to express our deepest gratitude and sincere appreciation to the following persons, whose guidance aided towards the competition of this paper. We would like to thank Dr. Myint Thein, Rector, Mandalay Technological University, for his kindness, help, permission and suggestion for completion of this paper. Special thanks are extended to Dr. Nilar Aye for her valuable suggestion and excellent comments to conduct this paper. We would like to thank our parents, teachers and all of friends for their support and encouragement throughout this research.

\section{REFERENCES}

[1] Pallavi Wamanrao Taywade, "Sustainability of structure using base isolation techniques for seismic protection", International Journal of Innovation Research in Science, Engineering and Technology, vol.4, Issue 3, ISSN 2319-8753, March 2015.

[2] An innovative isolation device for aseismic design, M.Ismail, J. Rode, F.Ikhouane, Engineering Structures 32, 1168-1183, 2010. https://doi.org/10.1016/j.engstruct.2009.12.043

[3] Investigation upon the dynamic structural response of a nuclear plant on a seismic isolation devices, I.Micheli, S.Cardini, A.Colaiuda, P.Turroni, Nuclear Engineering and Design 228, , 319-343, 2004. https://doi.org/10.1016/j.nucengdes.2003.06.028

[4] Earthquake Engineering Handbook, Wai-Fah Chen Charles Scawthorn, 2003.

[5] Ahmadi, S.L.; Tadjbakhsh, I.G. A comparative study of performances of various base isolation systems, Part 1: Shear beam structures, Earthquake. Engineering. Structural. Dynamic, 18, 11-32, 1989

https://doi.org/10.1002/eqe.4290180104

[6] Hussain RR, Saiful IABM, Ahmad SI, Base Isolators as Earthquake Protection Devices in Building, VDM Publishing House Ltd. Benoit Novel, Simultaneously publish in USA and U.K., p.140, 2010.

[7] Islam ABMS, Ahmad Si, AI-Hussaini TM, "Effect of Isolation on Buildings in Dhaka In, $3^{\text {rd }}$ International earthquake Symposium, BES ,5-6 March, Bangladesh, Dhaka,pp.465-472, 2010.

[8] H.P.Santhosh, K.S. Manjunath, and K.S.Kumar, "Seismic analysis of low to medium rise building for base isolation", International Journal of Research in Engineering and Technology, 2013.

[9] N.Torunbalci, G.Ozpalnlar, "Earthquake response analysis of mid-storey buildings isolated with various seismic isolation techniques", 14th world conference on Earthquake Engineering, vol.Oct.12-17, Beijing, China, 2008.

[10] Robinson, W.H. Lead-rubber hysteretic bearings suitable for protecting structures during earthquakes, Earthquake. Engineering. Structural Dynamic, 10, 593-604, 1982. https://doi.org/10.1002/eqe.4290100408

[11] S.M.Dhawade, "Comparative study for seismic performance of base isolated \& fixed base RC frame structure", International Journal of civil engineering research, vol.5, pp.183-190, 2014.

[12] N.R.Chandak, "Effect of base isolation on the response of reinforced concrete building", Journal of civil engineering Research, vol. 3(4), pp. 135-142, 2013.

[13] Young-Sang Kim-, "Study on the Effective Stiffness of Base Isolation System for Reducing Acceleration and Displacement Responses", Journal of the Korean Nuclear society, Volume 31, Number 6, pp.586-594, December 1999.

[14] T.E. Kelly, Base isolation of structures: Design guidelines. Wellington, New Zealand: Holmes Consulting Group Ltd, 2001.

[15] Earthquake Protection Systems, Inc, Technical characteristics of friction pendulum bearings, Vallejo, California, 2003.

[16] Computers and Structures, Inc. Steel Frame Design Manual AISC 360-05/IBC 2006. For ETABS (Version 9). (2010). 9 May 2013.

[17] Applied Technology Council (ATC). FEMA P-58: Seismic Performance Assessment of Buildings, Volume 2 - Implementation Guide. (2012). 26 March 2013.

[18] S.J.Patil, G.R.Reddy- "State Of Art Review-Base Isolation Systems For Structures", International Journal of Emerging Technology and Advanced Engineering, Volume 2, Issue 7, ISSN 2250-2459, July 2012. 


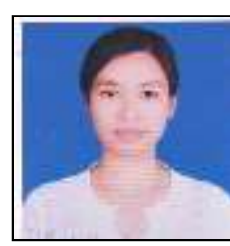

Author: Ms. Nwe Nwe Win is a $\mathrm{PhD}$ student in Department of Civil Engineering at Mandalay Technological University. She was born in Mandalay, Republic of the Union of Myanmar. Her date of birth is August 23, 1980. She got her Degree of Bachelor Engineering (Civil) from Technological University (Mandalay), Myanmar in 2004. Holding ME in civil Myanmar in 2011 engineering from Mandalay Technological University

Currently, she is doing her $\mathrm{PhD}$ research with a thesis title "Seismic, Performance Assessment of Steel Structures with Isolators" and about to finish it soon. I'm interested in studying the behavior of seismic isolated buildings. 